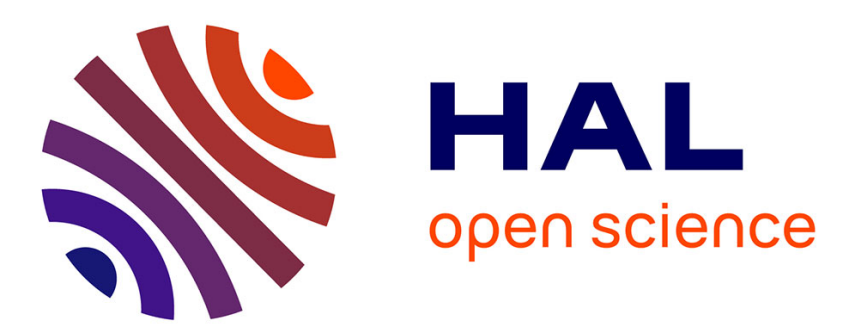

\title{
Bactericidal synergy of lysostaphin in combination with antimicrobial peptides
}

\author{
A. P. Desbois, P. J. Coote
}

\section{To cite this version:}

A. P. Desbois, P. J. Coote. Bactericidal synergy of lysostaphin in combination with antimicrobial peptides. European Journal of Clinical Microbiology and Infectious Diseases, 2011, 30 (8), pp.10151021. 10.1007/s10096-011-1188-z . hal-00669042

\section{HAL Id: hal-00669042 \\ https://hal.science/hal-00669042}

Submitted on 11 Feb 2012

HAL is a multi-disciplinary open access archive for the deposit and dissemination of scientific research documents, whether they are published or not. The documents may come from teaching and research institutions in France or abroad, or from public or private research centers.
L'archive ouverte pluridisciplinaire HAL, est destinée au dépôt et à la diffusion de documents scientifiques de niveau recherche, publiés ou non, émanant des établissements d'enseignement et de recherche français ou étrangers, des laboratoires publics ou privés. 


\section{BACTERICIDAL SYNERGY OF LYSOSTAPHIN IN COMBINATION WITH ANTIMICROBIAL PEPTIDES}

Andrew P. Desbois* and Peter J. Coote

Biomedical Sciences Research Complex, School of Biology, The North Haugh, University of St Andrews, Fife, KY16 9ST, UK.

*Author for correspondence: telephone +44 (0)1334 463417; fax +44 (0)1334 462595; email ad53@st-andrews.ac.uk

Keywords: antibacterial; colistin; daptomycin; drug resistance; MRSA; nasal carriage; nisin; polymyxin; staphylococci; Staphylococcus aureus. 


\begin{abstract}
Drug-resistant staphylococci are a serious problem that urgently requires the discovery of new therapeutic agents. There has been resurgence in interest for using lysostaphin (a specific anti-staphylococcal enzyme) as a treatment for infections caused by these important pathogens. However, bacterial resistance to lysostaphin is a problem but the use of a combination treatment may surmount this issue. In this present study, using viable counts from suspension incubations, lysostaphin is shown to be synergistically bactericidal in combination with various conventional antimicrobial peptides, the antimicrobial protein bovine lactoferrin, a lantibiotic (nisin), and certain lipopeptides used clinically (colistin, daptomycin and polymyxin B). Combinations that act in synergy are of clinical importance as these reduce the doses of the compounds needed for effective treatments and, most importantly, decrease the chances of resistance being selected. The use of lysostaphin in combination with a peptide may represent a new avenue to tackling drug-resistant staphylococci.
\end{abstract}

\title{
INTRODUCTION
}

Increased incidence of drug-resistant staphylococci has hastened the search for new compounds to treat infections caused by these pathogens. Since the 1960 s, one compound that has attracted attention as a potential anti-staphylococcal treatment is the endopeptidase lysostaphin $[1,2]$. This $27 \mathrm{kDa}$ enzyme specifically cleaves crosslinking pentaglycine bridges that are found exclusively in the staphylococcal cell wall [3]. Staphylococcus aureus is particularly susceptible to lysostaphin due to the very high proportion of pentaglycine bridges found within its cell wall [3]. Historically, lysostaphin suffered from problems with immunogenicity and reliability of supply but 
these issues have been resolved thanks to new technologies meaning that highly pure enzyme can be produced in great quantities [4-6]. This has seen renewed interest in using lysostaphin for antimicrobial applications [3,7-11]. Nonetheless, one drawback with lysostaphin is the high preponderance for bacterial resistance to be selected through mutations in $l y r A$ or the fem operon [12-14]. However, therapies that contain multiple antimicrobial agents can reduce the opportunity for resistance to be selected and various lysostaphin-containing combination treatments have been investigated, including lysostaphin with: i) various antibacterial drugs used clinically $[7,8,13,15-$ 20]; ii) tea tree oil [8]; iii) lysozyme [21]; iv) the phage lytic enzyme LysK [22]; and v) certain conventional antimicrobial peptides (AMPs) $[10,15,19,23]$. The incorporation of an AMP into a combination therapy further reduces the opportunity for bacterial resistance, as these compounds typically disrupt the bacterial cell membrane and resistance to AMPs is reported only rarely [24-27]. Moreover, certain lysostaphin/AMP combinations are synergistically antibacterial, which has clinical relevance as the doses of each compound can be reduced $[10,15]$. The synergistic bactericidal combination of lysostaphin with ranalexin (an AMP first isolated from the American bullfrog, Rana catesbeiana) is more effective against wound MRSA infections in a rabbit model than treatment with either component alone [10]. This combination retains synergistic antibacterial activity when incorporated into a gel meaning that it could also be used topically or intranasally to reduce patient carriage of staphylococci [28]. However, there is some indication of toxicity for ranalexin at higher concentrations in vitro [10] and the selection of a less toxic but similarly potent peptide partner for lysostaphin warrants investigation to improve the overall safety of the treatment. Thus, the aim of this present study was to investigate the scope of bactericidal synergy between lysostaphin and a spectrum of diverse antimicrobial 
peptides with the ultimate goal of providing new products for preventing and treating staphylococcal infections. The spectrum of peptides under examination in this study included conventional AMPs, lipopeptides, a lantibiotic and an antimicrobial protein. Amongst the conventional AMPs are peptides that form Gelices and $\delta_{\text {structures, }}$ with some examples of peptides containing disulphide bridges. In addition, there are certain non-natural AMPs, including two completely cyclic peptides, namely 6752 and GS14K4.

\section{MATERIALS AND METHODS}

\section{Reagents, culture media and micro-organisms}

Recombinant lysostaphin was purchased from AMBI (Lawrence, NY, USA) as a lyophilized powder (>93 \% purity; specific activity: >3500 units/mg). Culture media, bovine lactoferrin, colistin, nisin and polymyxin B were purchased from Sigma Aldrich Ltd. (Poole, UK). Daptomycin was purchased from Novartis Pharmaceuticals (Horsham, UK). All other antimicrobial peptides ( $>95 \%$ purity) were synthesized by Peptide Protein Research Ltd (Wickham, UK) according to the sequences given in Table 1. Peptide stocks and all other solutions were made with ultra pure deionised water (Maxima; Elga, High Wycombe, UK). Solutions and culture media were autoclaved at $121^{\circ} \mathrm{C}$ for $15 \mathrm{~min}$ or filter-sterilised (polyethersulfone $0.22 \mu \mathrm{m}$; Millipore, Watford, UK). S. aureus strains were sourced as described previously [10]. Bacterial suspensions were made in tryptone soy broth (TSB) using cultures, which had been grown to late-exponential phase in this medium at $220 \mathrm{rpm}$ and $37^{\circ} \mathrm{C}$. 


\section{Haemolysis assay}

The toxicity of each peptide was assessed by haemolysis using horse and sheep red blood cells (RBCs) according to the method of Desbois et al. [10]. To $100 \mu \mathrm{L} \mathrm{RBC}$ suspensions was added $0.5,1$ or $2 \mu \mathrm{L}$ of peptide solution to give concentrations of 32 , 64 and $128 \mathrm{mg} \mathrm{L}^{-1}$ (for nisin and polymyxin B greater volumes were added due to the stock solutions being slightly less concentrated). RBCs suspended in $1 \%$ sodium dodecyl sulphate were positive controls (100\% haemolysis). Percentage haemolysis at $4 \mathrm{~h}$ was calculated for each well.

\section{Suspension assay for bactericidal activity}

To wells on a 96-well plate was added $96 \mu \mathrm{L}$ bacterial suspensions in TSB $\left(1 \times 10^{6} \mathrm{cfu}\right.$ $\mathrm{mL}^{-1}$; exponential phase), which was made up to $100 \mu \mathrm{L}$ by the addition of stock solutions to give various final well concentrations of peptide alone, lysostaphin alone or peptide with lysostaphin. The concentrations of lysostaphin and/or peptide were selected for the assays on the basis of the susceptibility of each bacterium to the compound(s) under investigation and those that most effectively demonstrated the synergy between the compounds (up to a maximum $128 \mathrm{mg} \mathrm{L}^{-1}$ ). To control wells was added water only and each treatment was performed in quadruplicate. The plate was incubated $\left(37^{\circ} \mathrm{C} ; 24 \mathrm{~h} ; 1000 \mathrm{rpm}\right)$ on a microplate thermoshaker (PHMP; Grant Instruments Ltd., Shepreth, Cambs, UK). After incubation, viable bacteria were determined for each well by serial dilution in phosphate-buffered saline (PBS; for $1 \mathrm{~L}$ : $\left.8 \mathrm{~g} \mathrm{NaCl}, 0.2 \mathrm{~g} \mathrm{KCl}, 1.15 \mathrm{~g} \mathrm{Na}_{2} \mathrm{HPO}_{4}, 0.2 \mathrm{~g} \mathrm{KH}_{2} \mathrm{PO}_{4} ; \mathrm{pH} 7.3\right)$ and plating on tryptone soy agar (TSA). Plates were incubated $\left(37^{\circ} \mathrm{C} ; 24 \mathrm{~h}\right)$ and colony counts performed. The detection limit for each well was $100 \mathrm{cfu} \mathrm{mL}^{-1}$. The number of colonies recovered from replicate wells for each treatment were transformed by $\log _{10}$ and then averaged 
to give the geometric mean. Bactericidal synergy is defined as a $>2 \log _{10} \mathrm{cfu} \mathrm{mL}^{-1}$ reduction by the combination treatment compared to its most active constituent, providing that the number of viable bacteria recovered from the combination treatment is $>2 \log _{10} \mathrm{cfu} \mathrm{mL} \mathrm{m}^{-1}$ lower than the starting inoculum [30]. Further, at least one of the components in the combination must not affect the viability of the test organism when used alone [30].

\section{RESULTS}

Most of the peptides caused little or no haemolysis $(<2 \%$ haemolysis of horse or sheep RBCs even at $128 \mathrm{mg} \mathrm{L}^{-1}$ ) indicating that these probably have a low propensity for acute toxicity to mammalian cells (Table 1). Nigrocin caused $27.7 \%$ haemolysis of horse RBCs at $128 \mathrm{mg} \mathrm{L}^{-1}$ but this was still not as toxic as ranalexin, which caused $64.4 \%$ haemolysis at this concentration (Table 1).

In the bactericidal activity assays, when lysostaphin or each of the peptides were incubated individually with suspensions of $S$. aureus Newman (a methicillinsusceptible strain), these compounds had little or no effect on the number of viable bacteria recovered after $24 \mathrm{~h}$ compared with controls (Table 2). However, when lysostaphin was used in combination with each of the peptides (at the same concentrations as the individual incubations), counts of viable bacteria were reduced to such an extent that these treatments demonstrated synergistic bactericidal activity in each case. In many of the combinations, the number of viable bacteria recovered from the wells was at the limit of detection. Similar results were achieved using a methicillin-resistant (MRSA) strain, S. aureus BB270 (Table 3), thus confirming the 
synergistic bactericidal interactions between lysostaphin and the various peptides under investigation.

\section{DISCUSSION}

This present study shows for the first time bactericidal synergy for lysostaphin in combination with various conventional AMPs, lipopeptides and bovine lactoferrin.

In a previous study, while there were no signs of toxicity for lysostaphin/ranalexin combination treatments in animal infection models, ranalexin was toxic at high concentrations to horse RBCs and Vero cells [10]. Thus, it was deemed prudent to investigate a less toxic peptide partner for lysostaphin. In this present study, ranalexin is confirmed to be acutely toxic to horse RBCs at high concentrations but, with the exception of nigrocin, no other peptide used in this study is haemolytic.

Previous studies have shown that lysostaphin acts in synergy against $S$. aureus with certain antimicrobial peptides $[10,15,19]$. In the present study, the reported antibacterial synergy of lysostaphin with dermaseptin S3(1-16), magainin, polymyxin $\mathrm{B}$ and ranalexin is confirmed. Each of the other peptides used herein also acts in synergy with lysostaphin to kill staphylococci. Thus, lysostaphin renders $S$. aureus more susceptible to a broad spectrum of peptides, including conventional AMPs, lipopeptides, the lantibiotic nisin and the antimicrobial protein bovine lactoferrin. However, the synergies reported here have yet to be quantified and further studies to this end are warranted. Such investigations will identify the combinations with greatest promise for future anti-staphylococcal applications but, on initial inspection, some combinations appear more appealing as they contain compounds already used 
clinically (e.g. colistin, daptomycin and polymyxin B) or have been evaluated in clinical trials (e.g. pexiganan). In addition, any synergism observed in vitro must be evaluated in animal infection models to confirm that the favourable interaction is repeated in vivo because this cannot necessarily be assumed.

Lysostaphin kills staphylococcal bacteria by cleaving the pentaglycine bridges in the cell wall $[3,31]$, while most of the peptides used in this present study act against bacteria by affecting the integrity and functioning of the cell membrane [e.g. 25,3237]. Therefore, synergistic bactericidal activity could result from the peptides having greater access to the cell membrane thanks to the cell wall-degrading abilities of lysostaphin.

Lysostaphin has attracted renewed attention as a viable antimicrobial therapy in the light of increasingly prevalent multi-drug resistance. Reliable supplies of highly pure lysostaphin are now available and its use in combination with antimicrobial peptides may surmount the problem of bacterial resistance to lysostaphin alone [10]. Moreover, synergistic combinations have greater appeal as lower doses of the active compounds can be used. The vast majority of antimicrobial peptides tested in this present study act in synergy with lysostaphin and are non-toxic at effective concentrations meaning that they are highly suitable partners in combination treatments. Lysostaphin/peptide combinations may be suitable for topical decolonisation therapy in the prevention of infection but may also find application in wound therapy.

\section{ACKNOWLEDGMENTS}

No funding. 


\section{REFERENCES}

[1] Schindler CA, Schuhardt VT (1964) Lysostaphin: a new bacteriolytic agent for the Staphylococcus. Proc Nat Acad Sci 51:414-421.

[2] Martin RR, White A (1967) The selective activity of lysostaphin in vivo. J Lab Clin Med 70:1-8.

[3] Kumar JK (2008) Lysostaphin: an antistaphylococcal agent. Appl Microbiol Biotechnol 80:555-561.

[4] Mierau I, Leij P, van Swam I, Blommestein B, Floris E, Mond J, Smid EJ (2005) Industrial-scale production and purification of a heterologous protein in Lactococcus lactis using the nisin-controlled gene expression system NICE: The case of lysostaphin. Microb Cell Fact 4:15.

[5] Sharma R, Sharma PR, Choudhary ML, Pande A, Khatri GS (2006) Cytoplasmic expression of mature glycylglycine endopeptidase lysostaphin with an amino terminal hexa-histidine in a soluble and catalytically active form in Escherichia coli. Protein Expr Purif 45:206-215.

[6] Szweda P, Kotłowski R, Kur J (2005) New effective sources of the Staphylococcus simulans lysostaphin. J Biotechnol 117:203-213.

[7] Kokai-Kun JF, Chanturiya T, Mond JJ (2007) Lysostaphin as a treatment for systemic Staphylococcus aureus infection in a mouse model. J Antimicrob Chemother 60:1051-1059.

[8] LaPlante KL (2007) In vitro activity of lysostaphin, mupirocin, and tea tree oil against clinical methicillin-resistant Staphylococcus aureus. Diagn Microbiol Infect Dis 57:413-418. 
[9] Placencia FX, Kong L, Weisman LE (2009) Treatment of methicillin-resistant

Staphylococcus aureus in neonatal mice: Lysostaphin versus vancomycin. Pediatr Res $65: 420-424$.

[10] Desbois AP, Gemmell CG, Coote PJ (2010) In vivo efficacy of the antimicrobial peptide ranalexin in combination with the endopeptidase lysostaphin against wound and systemic meticillin-resistant Staphylococcus aureus (MRSA) infections. Int J Antimicrob Agents 35:559-565.

[11] Pangule RC, Brooks SJ, Dinu CZ, Bale SS, Salmon SL, Zhu G, Metzger DW, Kane RS, Dordick JS (2010) Antistaphylococcal nanocomposite films based on enzyme-nanotube conjugates. ACS Nano 4:3993-4000.

[12] Boyle-Vavra S, Carey RB, Daum RS (2001) Development of vancomycin and lysostaphin resistance in a methicillin-resistant Staphylococcus aureus isolate. J Antimicrob Chemother 48:617-625.

[13] Climo MW, Ehlert K, Archer GL (2001) Mechanism and suppression of lysostaphin resistance in oxacillin-resistant Staphylococcus aureus. Antimicrob Agents Chemother 45:1431-1437.

[14] Gründling A, Missiakas DM, Schneewind O (2006) Staphylococcus aureus mutants with increased lysostaphin resistance. J Bacteriol 188:6286-6297. [15] Polak J, Latta PD, Blackburn P (1993) In vitro activity of recombinant lysostaphin-antibiotic combinations toward methicillin-resistant Staphylococcus aureus. Diagn Microbiol Infect Dis 17:265-270.

[16] Climo MW, Patron RL, Goldstein BP, Archer GL (1998) Lysostaphin treatment of experimental methicillin-resistant Staphylococcus aureus aortic valve endocarditis. Antimicrob Agents Chemother 42:1355-1360. 
[17] Kiri N, Archer G, Climo MW (2002) Combinations of lysostaphin with $\delta$ lactams are synergistic against oxacillin-resistant Staphylococcus epidermidis. Antimicrob Agents Chemother 46:2017-2020.

[18] Walencka E, Sadowska B, Różalska S, Hryniewicz W, Różalska B (2006) Staphylococcus aureus biofilm as a target for single or repeated doses of oxacillin, vancomycin, linezolid and/or lysostaphin. Folia Microbiol 51: 381-386.

[19] Graham S, Coote PJ (2007) Potent, synergistic inhibition of Staphylococcus aureus upon exposure to a combination of the endopeptidase lysostaphin and the cationic peptide ranalexin. J Antimicrob Chemother 59:759-762.

[20] Kokai-Kun JF, Chanturiya T, Mond JJ (2009) Lysostaphin eradicates established Staphylococcus aureus biofilms in jugular vein catheterized mice. J Antimicrob Chemother 64:94-100.

[21] Cisani G, Varaldo PE, Grazi G, Soro O (1982) High-level potentiation of lysostaphin anti-staphylococcal activity by lysozyme. Antimicrob Agents Chemother 21:531-535.

[22] Becker SC, Foster-Frey J, Donovan DM (2008) The phage K lytic enzyme LysK and lysostaphin act synergistically to kill MRSA. FEMS Microbiol Lett 287:185-191. [23] Walsh SM, Shah AG, Mond JJ (2004) Topical anti-infective formulations. US Patent publication no. US 2004/0192581 A1.

[24] Hancock REW (1997) Peptide antibiotics. Lancet 349:418-422.

[25] Yeaman MR, Yount NY (2003) Mechanisms of antimicrobial peptide action and resistance. Phamacol Rev 55:27-55.

[26] Marr AK, Gooderham WJ, Hancock REW (2006) Antibacterial peptides for therapeutic use: obstacles and realistic outlook. Curr Opin Pharmacol 6:468-472. 
[27] Perron GG, Zasloff M, Bell G (2006) Experimental evolution of resistance to an antimicrobial peptide. Proc R Soc B 273:251-256.

[28] Desbois AP, Lang S, Gemmell CG, Coote PJ (2010) Surface disinfection properties of the combination of an antimicrobial peptide, ranalexin, with an endopeptidase, lysostaphin, against methicillin-resistant Staphylococcus aureus (MRSA). J Appl Microbiol 108:723-730.

[29] Mead PE, Tweedie JW (1990) cDNA and protein sequence of bovine lactoferrin. Nuc Acids Res 18:7167.

[30] White RL, Burgess DS, Mandura M, Bosso JA (1996) Comparison of three different in vitro methods of detecting synergy: time-kill, checkerboard, and $\mathrm{E}$ test. Antimicrob Agents Chemother 40:1914-1918.

[31] Francius G, Domenech O, Mingeot-Leclercq MP, Dufrêne YF (2008) Direct observation of Staphylococcus aureus cell wall digestion by lysostaphin. J Bacteriol 190:7904-7909.

[32] Scholar EM, Pratt WB (2000) Antibiotics that affect membrane permeability. In: Scholar EM and Pratt WB (eds) The Antimicrobial Drugs, $2^{\text {nd }}$ edn. Oxford University Press, New York, pp 234-241.

[33] Bechinger B, Lohner K (2006) Detergent-like actions of linear amphipathic cationic antimicrobial peptides. Biochim Biophys Acta 1758:1529-1539. [34] Moraes LGM, Fázio M, Vieira RFF, Nakaie CR, Miranda MTM, Schreier S, Daffre S, Miranda A (2007) Conformational and functional studies of gomesin analogues by CD, EPR and fluorescence spectroscopies. Biochim Biophys Acta 1768:52-58.

[35] Willey JM, van der Donk WA (2007) Lantibiotics: Peptides of diverse structure and function. Annu Rev Microbiol 61:477-501. 
[36] Gottler L, Ramamoorthy A (2009) Membrane orientation, mechanism, and function of pexiganan - a highly potent antimicrobial peptide designed from magainin. Biochim Biophys Acta 1788:1680-1686

[37] Robbel L, Marahiel MA (2010) Daptomycin, a bacterial lipopeptide synthesized by a nonribosomal machinery. J Biol Chem 285:27501-27508. 
Table 1. Peptides used in this study: their lengths, sequences and haemolytic activities. Haemolysis was assessed against horse and sheep red blood cells (RBCs) during $4 \mathrm{~h}$ incubation with shaking at $37^{\circ} \mathrm{C}$. No haemolysis was recorded in negative control wells that had only water added. $\mathrm{n}=4$.

$$
\text { Peptide Length Sequence }
$$

(aa)
Haemolysis (\%)

Horse RBCs Concentration ( $\left.\mathrm{mg} \mathrm{L}^{-1}\right) \quad$ Concentration $\begin{array}{lllll}32 & 64 & 128 & 32 & 64\end{array}$

\section{Conventional AMPs forming Shelices (linear)}

Dermaseptin-S3 (1-16) 16

KR-20

Magainin-2

20

Nigrocin-OG13

Pexiganan

23

21

22

ALWKNMLKGIGKLAGK
KRIVQRIKDFLRNLVPRTES
GIGKFLHSAKKFGKAFVGEIMNS
GLLSGILGAGKHIVCGLSGLR
GIGKFLKKAKKFGKAFVKILKK

ALWKNMLKGIGKLAGK

$\begin{array}{ccccc}0 & 0 & 0 & 0 & 0 \\ 0 & 0 & 0 & 0 & 0 \\ 0 & 0 & 0 & 0 & 0 \\ 0.2 & 8.2 & 27.7 & 1.0 & 0 \\ 0 & 0 & 0.1 & 0 & 0\end{array}$

Conventional AMPs forming Shelices (and contain a disulphide bridge)

\begin{tabular}{|c|c|c|c|c|c|c|}
\hline MUC7-12mer ${ }^{a}$ & 12 & RKSYKCLHKRCR & 0 & 0 & 0 & 0 \\
\hline Ranalexin $^{a}$ & 20 & FLGGLIKIVPAMICAVTKKC & 0.9 & 16.5 & 64.4 & 0 \\
\hline
\end{tabular}

Conventional AMPs forming ofstructures

\begin{tabular}{|c|c|c|c|c|c|c|}
\hline Gomesin $^{b}$ & 19 & (E)CRRLCYKQRCVTYCRGR & 0 & 0 & 0 & 0 \\
\hline GS14K4 & 14 & VKLkVyPLKVKLyP & 0 & 0 & 0.4 & 0 \\
\hline Melanotropin-б & 13 & Ac-SYSMEHFRWGKPV-NH ${ }_{2}$ & 0 & 0 & 0 & 0 \\
\hline
\end{tabular}

Conventional AMPs of unknown structure

6752

hLF (1-11)

Parasin-I

11

Odorranain-G1 ${ }^{\text {a }}$

\section{Lantibiotic}

Nisin

$$
\begin{gathered}
\text { IBAIALAJPGAKJGALMGANM } \\
\text { JAHASIHVAKK } \\
\text { *BTBBBILBBT } \\
* * \text { WNDTGOdADgSEU } \\
* \text { BTBBBfLBBT }
\end{gathered}
$$

\author{
*BTBBBILBBT \\ **WNDTGOdADgSEU \\ *BTBBBfLBBT
}

SwFkTkSk GRRRRSVQWCA KGRGKQGGKVRAKAKTRSS FMPILSCSRFKRC

$\begin{array}{lllll}0 & 0 & 0 & 0 & 0 \\ 0 & 0 & 0 & 0 & 0 \\ 0 & 0 & 0 & 0 & 0 \\ 0 & 0 & 0 & 0 & 0\end{array}$

Lipopeptides

Colistinc

Daptomycin

Polymyxin Bd

\section{Protein}

Bovine lactoferrin

Lower case indicates a D-amino acid.

$\mathrm{Ac}=$ acetylated at $\mathrm{N}$-terminus $; \underline{\mathrm{A}}=$ dehydroalanine $; \mathrm{B}=$ diaminobutyric acid $; \underline{\mathrm{B}}=$ dehydrobutyrine; $(\mathrm{E})=$ pyroglutamic acid $; \underline{\mathrm{E}}=$ methylglutamic acid $; \mathrm{J}=$ aminobutyric 
acid; $\mathrm{NH}_{2}=$ amidated at $\mathrm{C}$-terminus; $\mathrm{O}=$ ornithine; $\mathrm{U}=$ kynurenine; * = 6methyloctanoyl chain; $* *=$ decanoyl chain.

${ }^{a}$ intact disulphide bridge forming a loop.

${ }^{\mathrm{b}}$ two intact disulphide bridges forming a \&hairpin.

${ }^{c}$ the structure is given for the major constituent polymyxin E1; the minor constituent polymyxin E2 has a 6-methylhaptanoyl chain.

${ }^{d}$ the structure is given for the major constituent polymyxin B1; the minor constituent polymyxin B2 has a 6-methylhaptanoyl chain. 
Table 2. Effect on the viable counts of $S$. aureus Newman during 24 h exposure to lysostaphin alone, peptide alone or lysostaphin in combination with a peptide. Each lysostaphin/AMP combination acted in synergy to reduce the viable counts of bacteria.

The lower detection limit was $100 \mathrm{cfu} \mathrm{mL}^{-1} . \mathrm{n}=4$; data given as: mean (SD).

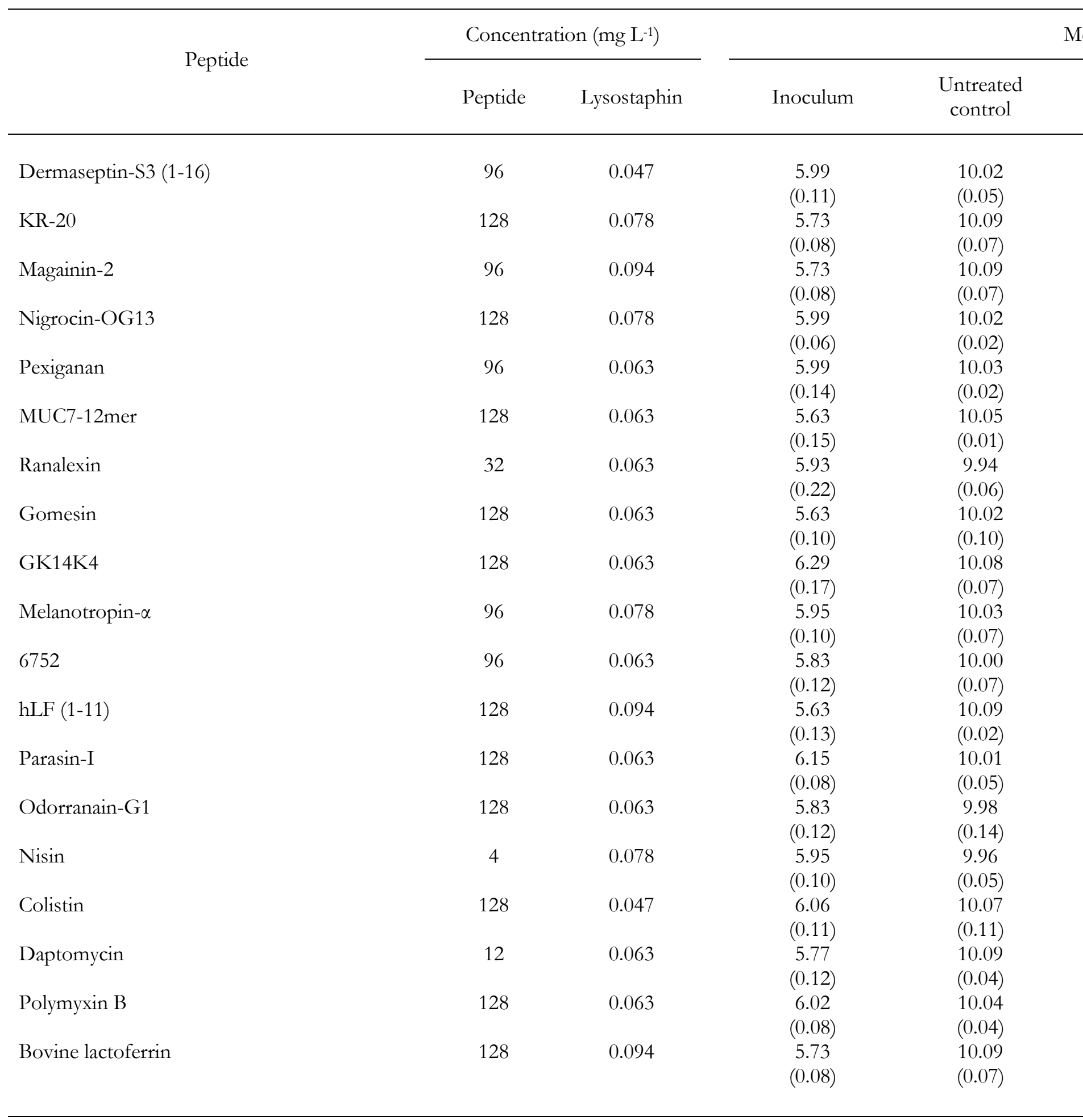


Table 3. Effect on the viable counts of $S$. aureus BB270 during 24 h exposure to lysostaphin alone, peptide alone or lysostaphin in combination with a peptide. Each lysostaphin/AMP combination acted in synergy to reduce the viable counts of bacteria.

The lower detection limit was $100 \mathrm{cfu} \mathrm{mL}^{-1} . \mathrm{n}=4$; data given as: mean (SD).

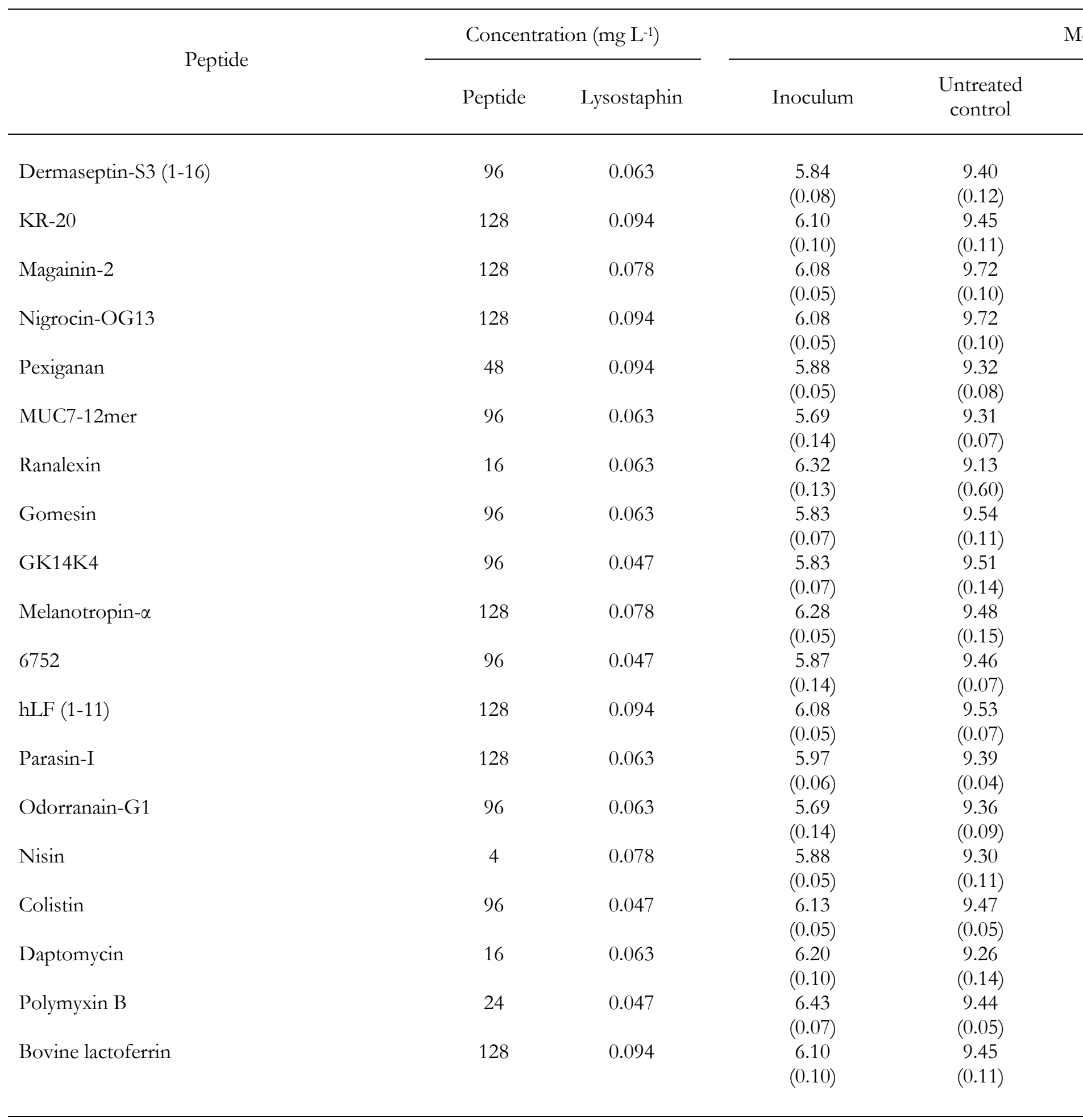


